\title{
Wewenang Jaksa sebagai Pelaksana Putusan Eksekutorial Putusan Pengadilan yang Telah Mempunyai Kekuatan Hukum Tetap
}

\author{
The Authority of Prosecutors as Executorial Decisions of Court Decisions that \\ Have Permanent Legal Power
}

\author{
Daniar Rasyid Setya Wardhana1, Dicky Andi Firmansyah², \\ Er Handaya Artha Wijaya ${ }^{3}$, Yugo Susandi ${ }^{4}$ \\ 1. Universitas Airlangga, Indonesia. E-mail: roycegunner619@gmail.com \\ 2. Universitas Airlangga, Indonesia. E-mail: mi6ovice@gmail.com \\ 3. Universitas Airlangga, Indonesia. E-mail: conroyk517@gmail.com \\ 4. Universitas Airlangga, Indonesia. E-mail: metalgearamy@gmail.com
}

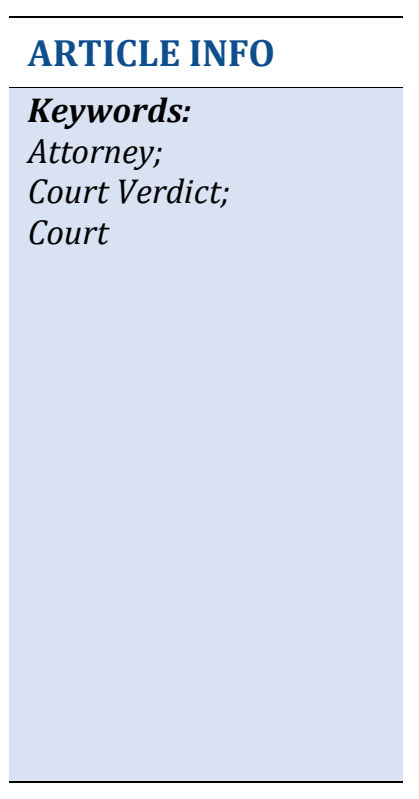

\section{INFO ARTIKEL}

Kata kunci:
Jaksa;
Putusan Pengadilan;
Pengadilan

\begin{abstract}
A Court Verdict can be executed if the ruling has remained legal force. Legally, the implementation of the ruling is done by law enforcement, namely prosecutors who are under the auspices of the Republic of Indonesia prosecutor. The authority of the Prosecutor as the executor of the court ruling that has had a fixed legal force based on article 270 KUHAP, stating that the implementation of the court ruling that has acquired the legal force remains done by the prosecutor, for which the clerk sent a copy of the ruling letter to him; Article 30 paragraph (3) letter (b) of Law No. 16 ofyear 2004 concerning the attorney of the Republic of Indonesia, which mentions That criminal field, prosecutors have duties and authority to carry out the determination of judges and court decisions that acquire the power of permanent law; and article 54 paragraph (1) of Law No. 48 year 2009 on judicial authority, which mentions that the implementation of a court ruling in criminal matters is done by prosecutors. In conducting the execution of the Prosecutor's Court should pay attention to the value of humanity and justice and should be able to position his position as independent institution free from interference of any party.
\end{abstract}


Tahun 2004 tentang Kejaksaan Republik Indonesia, yang menyebutkan bahwa dibidang pidana, kejaksaan mempunyai tugas dan wewenang melaksanakan penetapan hakim dan putusan pengadilan yang memperoleh kekuatan hukum tetap; serta Pasal 54 ayat (1) Undang-Undang Nomor 48 Tahun 2009 tentang Kekuasaan Kehakiman, yang menyebutkan bahwa pelaksanaan putusan pengadilan dalam perkara pidana dilakukan oleh jaksa. Dalam melakukan pelaksanaan putusan atau eksekusi jaksa harus memperhatikan nilai kemanusiaan dan keadilan serta harus dapat memosisikan kedudukannya sebagai lembaga independen yang bebas dari campur tangan pihak mana pun.

\section{Pendahuluan}

Dalam perbincangan bahasa hukum sehari-hari, pelaksanaan putusan pengadilan lebih dikenal dengan sebutan eksekusi. Namun, secara yuridis dalam Bab XIX KUHAP, disebutkan dengan istilah pelaksanaan putusan pengadilan. Berdasarkan kamus bahasa Indonesia, pengertian eksekusi adalah pelaksanaan putusan hakim. Pengertian putusan pengadilan dan putusan hakim pada dasarnya sama, hanya perbedaan istilah saja. Putusan pengadilan lebih mengedepankan institusi pengadilan, sedangkan putusan hakim lebih spesifik teknis menunjuk kepada pejabat, yakni hakim yang membuat putusan ${ }^{1}$.

Pasal 1 butir 11 KUHAP, menyebutkan bahwa yang dimaksud dengan putusan pengadilan adalah pernyataan hakim yang diucapkan dalam siding pengadilan terbuka, yang dapat berupa pemidanaan atau bebas atau lepas dari segala tuntutan hukum, dalam hal serta menurut cara yang diatur undang-undang.

Semua putusan pengadilan mempunyai kekuatan eksekutorial yaitu kekuatan untuk dilaksanakan secara paksa oleh alat-alat Negara. Suatu putusan pengadilan dikatakan mempunyai kekuatan eksekutorial karena adanya kepala putusan, yang berbunyi: "Demi Keadilan Berdasarkan Ketuhanan Yang Maha Esa" 2. Hal ini ditujukan agar setiap putusan pengadilan melahirkan suatu putusan yang mempunyai kekuatan eksekutorial yang artinya bahwa putusan tersebut bisa dilakukan secara paksa jika ada pihak yang dikalahkan namun tidak mau secara sukarela melaksanakan isi putusan tersebut ${ }^{3}$. Namun tidak semua putusan pengadilan dalam melaksanakannya dilakukan secara paksa oleh alat-alat Negara, tetapi hanya putusan pengadilan yang diktumnya bersifat "condemnatoir", sedangkan putusan yang diktumnya bersifat declaratoir dan constitutive tidak memerlukan sarana-sarana untuk melaksanakannya ${ }^{4}$.

1 Tim Penyusun Modul Badan Diklat Kejaksaan RI, Modul Eksekusi (Jakarta: Badan Pendidikan dan Pelatihan Kejaksaan Republik Indonesia, 2019), 4.

2 Riduan Bakti Syahrani, Materi Dasar Hukum Acara Perdata (Bandung: Citra Aditya Bakti, 2000), 117.

3 Dahlan Sinaga, Kemandirian dan Kebebasan Hakim Memutus Perkara Pidana dalam Negara Hukum Pancasila, Suatu Perspektif Teori Keadilan Bermartabat, Bandung. (Nusa Media, 2015), 127; dalam Samuel Saut Martua Samosir, "Penerapan Penggunaan Irah-Irah 'Demi Keadilan Berdasarkan Ketuhanan Yang Maha Esa' dalam Konteks Pencapaian Keadilan,” Jurnal Supremasi 9, no. 2 (2019): 7, https://ejournal.unisbablitar.ac.id/index.php/supremasi/article/view/790.

4 Syahrani, Materi Dasar Hukum Acara Perdata, 117. 
Secara teori dan praktik, putusan pengadilan dapat dieksekusi apabila putusan telah berkekuatan hukum tetap. Pelaksanaan putusan pengadilan atau eksekusi yang telah berkekuatan hukum tetap (in kracht van gewijde) dalam perkara pidana merupakan bagian dari penegakan hukum pidana ${ }^{5}$ Secara hukum, pelaksanaan putusan tersebut dilakukan oleh penegak hukum, yakni jaksa yang berada di bawah naungan lembaga Kejaksaan Republik Indonesia.

Keberadaan institusi Kejaksaan Republik Indonesia pada saat ini ialah Undang-Undang Nomor 16 Tahun 2004 tentang Kejaksaan. Menurut ketentuan dalam Pasal 2 Ayat (1) Undang-Undang Kejaksaan, menyebutkan bahwa Kejaksaan Republik Indonesia merupakan lembaga pemerintah yang melaksanakan kekuasaan Negara dibidang penuntutan serta kewenangan lain berdasarkan undang-undang6.

Jaksa itu sendiri merupakan pejabat fungsional yang diberi kewenangan oleh undangundang untuk bertindak sebagai penuntut umum dan pelaksanaan putusan pengadilan yang telah memperoleh kekuatan hukum tetap serta wewenang lain berdasarkan undangundang. Peran yang demikian menuntut seorang jaksa tidak hanya menguasai disiplin hukum pidana, tetapi juga disiplin hukum perdata dan tata usaha negara. Jaksa tidak hanya dituntut menguasai hukum positif yang bersifat umum (lex generalis) tetapi juga yang bersifat khusus (lex specialis) yang banyak lahir akhir-akhir ini ${ }^{7}$.

Adapun wewenang jaksa dalam melakukan pelaksanaan putusan pengadilan diatur dalam beberapa pasal yakni Pasal 270 KUHAP, yang menyatakan bahwa pelaksanaan putusan pengadilan yang telah memperoleh kekuatan hukum tetap dilakukan oleh jaksa, yang untuk itu panitera mengirimkan salinan surat putusan kepadanya. Pasal 30 ayat (3) huruf (b) Undang-Undang Nomor 16 Tahun 2004 tentang Kejaksaan Republik Indonesia, yang menyebutkan bahwa dibidang pidana, kejaksaan mempunyai tugas dan wewenang melaksanakan penetapan hakim dan putusan pengadilan yang memperoleh kekuatan hukum tetap. Serta Pasal 54 ayat (1) Undang-Undang Nomor 48 Tahun 2009 tentang Kekuasaan Kehakiman, yang menyebutkan bahwa pelaksanaan putusan pengadilan dalam perkara pidana dilakukan oleh jaksa. Dalam melakukan pelaksanaan putusan atau eksekusi jaksa harus memperhatikan nilai kemanusiaan dan keadilan. Oleh karena itu isu hukum dalam penelitian ini adalah apakah kewenangan jaksa membolehkan pelaksanaan putusan tetap di luar kewenangannya atau semata-mata hanya memperhatikan sisi kemanusiaan dan keadilan.

5 R Indra, "Pelaksanaan Putusan (Eksekusi) Perkara Pidana yang Berkekuatan Hukum Tetap," Doktor Hukum, last modified 2019, diakses Mei 2, 2020, https://www.doktorhukum.com/pelaksanaan-putusaneksekusi-perkara-pidana-yang-berkekuatan-hukum-tetap/.

6 Marwan Effendy, Kejaksaan Republik Indonesia, Posisi dan Fungsinya dari Perspektif Hukum (Jakarta: Ghalia Indonesia, 2007), 127.

7 Kelik Pramudya dan Ananto Widiatmoko, Pedoman Etika Profesi Aparat Hukum (Jakarta: Pustaka Yustisia, 2010), 39. 


\section{Metode}

Penelitian ini merupakan penelitian hukum. Menurut Morris L. Cohen, "legal research is the process of finding the law that governs activities in human society" ${ }^{\text {. Kegiatan penelitian }}$ hukum adalah untuk memperoleh kebenaran koherensi. Kegiatan ini berpangkal dari tolok ukur yang berupa moral. Norma yang berupa pedoman tingkah laku harus berlandaskan prinsip hukum yang selanjutnya berpangkal kepada moral. Aturan hukum harus koheren dengan norma hukum dan norma hukum koheren dengan prinsip hukum ${ }^{9}$. Penelitian hukum untuk karya akademis juga harus menemukan preskripsi yang dapat diterapkan dan koheren dengan prinsip hukum yang merefleksikan moral ${ }^{10}$.

Sedangkan pendekatan yang digunakan dalam penelitian ini adalah pendekatan peraturan perundang-undangan (statute approach). Pendekatan perundang-undangan (statute approach) dilakukan dengan menelaah semua undang-undang dan regulasi yang bersangkut paut dengan isu hukum yang sedang ditangani ${ }^{11}$.

\section{Tinjauan Umum tentang Putusan Pengadilan}

\subsection{Ruang lingkup putusan pengadilan}

Ruang lingkup pelaksanaan putusan pengadilan meliputi:

a. Pelaksanaan putusan pengadilan mengenai pidana pokok (pidana mati, pidana badan penjara/kurungan, serta pidana denda);

b. Pelaksanaan putusan pengadilan mengenai pidana tambahan, meliputi pencabutan hak-hak tertentu, perampasan barang-barang tertentu, pengumuman putusan hakim, serta pidana tambahan lainnya yang diatur dalam ketentuan perundang-undangan khusus, antara lain berupa uang pengganti yang diatur dalam Undang-Undang Nomor 31 Tahun 1999 tentang Pemberantasan Tindak Pidana Korupsi, jo. Undang-Undang Nomor 20 Tahun 2001 tentang Perubahan atas Undang-Undang Nomor 31 Tahun 1999 tentang Pemberantasan Tindak Pidana Korupsi.

\subsection{Dasar hukum putusan pengadilan}

Dasar hukum pelaksanaan putusan pengadilan, antara lain:

a. Pasal 1 angka 6 huruf (a) KUHAP;

b. Pasal 270 sampai dengan pasal 276 KUHAP. Ketentuan-ketentuan dalam KUHAP bersifat umum, sehingga dalam pelaksanaannya masih harus disesuaikan dengan ketentuan acara khusus dari berbagai perundang-undangan lain (lex spesialis derogate legi generali);

8 Peter Mahmud Marzuki, Penelitian Hukum, 12 ed. (Jakarta: Kencana, 2016), 57; dikutip dari Morris L. Cohen dan Kent C. Oslon, Legal Research (St. Paul, Minn: West Publishing Company, 1992), 1.

9 Marzuki, Penelitian Hukum, 64.

10 Ibid., 81-82.

11 Ibid., 133. 
c. Pasal 30 ayat (1) huruf b Undang-undang Nomor 16 Tahun 2004 tentang Kejaksaan RI;

d. Pasal 54 ayat (1) Undang-undang Nomor 48 Tahun 2009 tentang Kekuasaan Kehakiman: Pelaksanaan Putusan Pengadilan dalam perkara pidana dilakukan oleh Jaksa;

e. Undang-undang Nomor 2/PNPS/Tahun 1964 tentang Tata Cara Pelaksanaan Pidana Mati yang Dijatuhkan oleh Pengadilan di Lingkungan Peradilan Umum dan Militer;

f. Peraturan Jaksa Agung Republik Indonesia Nomor: PER-036/A/JA/09/2011, tanggal 21 September 2011, Pasal 48 tentang SOP Pidum;

Dasar hukum tiap jenis putusan pengadilan sebagai berikut:

1. Ketentuan pelaksanaan putusan pengadilan pidana badan

a. Pasal 12 sampai dengan 14 KUHP tentang pidana penjara;

b. Pasal 14a sampai dengan 14f KUHP tentang pidana bersyarat;

c. Pasal 18 sampai dengan pasal 23 KUHP tentang pidana kurungan;

d. Pasal 271, Pasal 272, Pasal 276 KUHAP;

e. Undang-Undang Nomor 2/PNPS/Tahun 1964 tentang Tata Cara Pelaksanaan Pidana Mati yang Dijatuhkan oleh Pengadilan di Lingkungan Peradilan Umum dan Militer;

f. Undang-Undang Nomor 22 Tahun 2002 tentang Grasi sebagaimana diubah dengan UU Nomor 5 Tahun 2010

g. Surat Jaksa Agung Muda Tindak Pidana Umum Nomor B-235/ E/3/1994 tanggal 4 Maret 1994 perihal eksekusi putusan pengadilan;

h. Surat Jaksa Agung Muda Tindak Pidana Umum Nomor: B-128/E/3/1996 tanggal 8 Maret 1996 perihal tugas dan tanggung jawab Jaksa selaku eksekutor putusan Pengadilan;

i. Instruksi Jaksa Agung RI Nomor: INS-006/JA/4/1995 tanggal 24 April 1995 tentang petunjuk pelaksanaan penanganan perkara pidana umum;

j. Keputusan Jaksa Agung RI Nomor: KEP-518/A/JA/11/2001 tanggal 1 November 2001 tentang Perubahan Keputusan Jaksa Agung RI Nomor: KEP132/11/1944 tentang Administrasi Perkara Tindak Pidana.

\subsection{Ketentuan yang mengatur pelaksanaan putusan pengadilan mengenai denda,} biaya perkara, barang bukti dan pembayaran uang pengganti

\subsubsection{Ketentuan yang mengatur pelaksanaan putusan mengenai denda dan biaya perkara}

Ketentuan yang mengatur pelaksanaan putusan pengadilan mengenai denda dan biaya perkara, antara lain:

a. Pasal 30, Pasal 31 ayat (3) KUHP tentang Denda;

b. Pasal 273 ayat (1) dan (2) KUHAP tentang Denda;

c. Pasal 222, pasal 275 KUHAP tentang Biaya Perkara; 
d. Undang-undang Nomor 22 Tahun 2002 tentang Grasi sebagaimana diubah dengan UU Nomor 5 Tahun 2010;

e. Surat Edaran Jaksa Agung RI Nomor: SE-008/JA/7/1981 tanggal 23 Juli 1981 tentang Ongkos Perkara;

f. Surat Edaran Jaksa Agung RI Nomor: SE-009/JA/9/1983 tanggal 12 September 1983 tentang Tata Cara Penanganan Uang Denda dan Biara Perkara;

g. Surat Edaran Jaksa Agung Muda Tindak Pidana Umum Nomor: SE-235/E/3/ 1994 tanggal 4 Maret 1994, perihal Eksekusi Putusan Pengadilan;

h. Instruksi Jaksa Agung RI Nomor: INS-006/JA/4/1995 tanggal 24 April 1995 tentang Petunjuk Pelaksanaan Penanganan Perkara Tindak Pidana Umum;

i. Keputusan Jaksa Agung RI Nomor: KEP-518/A/JA/11/2001 tanggal 1 November 2001 tentang Perubahan Keputusan Jaksa Agung RI Nomor: KEP132/JA/11/1994 tentang Administrasi Perkara Tindak Pidana.

\subsubsection{Ketentuan yang mengatur pelaksanaan putusan mengenai barang bukti}

Ketentuan mengenai barang bukti yakni:

a. Pasal 46 ayat (2) KUHAP;

b. Pasal 194 KUHAP dan Pasal 273 ayat (3) dan ayat (4) KUHAP;

c. Surat Edaran Jaksa Agung RI Nomor: SE-011/JA/10/1983 tanggal 26 Oktober 1983 tentang Penyelesaian Barang Rampasan Khusus Senjata Api, Mesin dan Bahan Peledak;

d. Keputusan Jaksa Agung RI Nomor: KEP-089/JA/08/1988 tanggal 5 Agustus 1988 tentang Penyelesaian Barang Rampasan;

e. Surat Edaran Jaksa Agung RI Nomor: SE-003/B/B.5/08/1988 tanggal 6 Agustus 1988 tentang Penyelesaian Barang Rampasan;

f. Surat Edaran Jaksa Agung RI Nomor: SE-001/B/B 5/02/1993 tanggal 2 Februari 1993 tentang Perubahan atas Surat Edaran Nomor: SE05/B/B.5/8/1988 tanggal 6 Agustus 1988;

g. Surat Jaksa Agung Muda Tindak Pidana Umum Nomor: B-235/E/3/1994 tanggal 4 Maret 1994 perihal Eksekusi Putusan Pengadilan.

3.3.3. Ketentuan yang mengatur pelaksanaan putusan mengenai pembayaran uang pengganti

Ketentuan yang mengatur pelaksanaan putusan pengadilan mengenai pembayaran uang pengganti, yakni:

a. Pasal 34 sub (c) Undang-Undang Republik Indonesia Nomor 3 Tahun 1971 tentang Pemberantasan Tindak Pidana Korupsi;

b. Pasal 18 ayat (1), ayat (2) dan ayat (3) Undang-Undang Republik Indonesia Nomor 31 Tahun 1999 tentang Pemberantasan Tindak Pidana Korupsi; 
c. Surat Edaran Mahkamah Agung RI Nomor: 4 Tahun 1983 tanggal 7 Juli 1983 tentang Eksekusi Terhadap Hukuman Tambahan Pembayaran Uang Pengganti.; serta

d. Surat Edaran Jaksa Agung RI Nomor: SE-004/JA/8/1983 tanggal 5 Agustus 1988 tentang Pelaksanaan Pidana Tambahan Pembayaran Uang Pengganti.

\subsection{Jenis dan karakteristik putusan pengadilan}

Jenis-jenis putusan pengadilan di antaranya meliputi12:

a. Putusan pengadilan yang berupa pemidanaan

Putusan pengadilan pemidanaan adalah putusan yang dikeluarkan berdasarkan pemeriksaan di persidangan pengadilan, majelis hakim berpendapat bahwa terdakwa terbukti secara syah dan meyakinkan bersalah telah melakukan tindak pidana yang didakwakan kepadanya maka pengadilan menjatuhkan pidana sebagaimana ditentukan dalam pasal 193 ayat (1) KUHAP.

b. Putusan pengadilan yang berupa pembebasan dari segala dakwaan (vrijspraak)

Putusan pengadilan berupa pembebasan adalah putusan yang dikeluarkan berdasarkan pemeriksaan di persidangan pengadilan, majelis hakim berpendapat bahwa terdakwa tidak terbukti secara syah dan meyakinkan bersalah telah melakukan tindak pidana yang didakwakan kepadanya maka pengadilan membebaskan dari segala dakwaan sebagaimana ditentukan dalam asal 191 ayat (1) KUHAP.

c. Putusan pengadilan yang berupa lepas dari segala tuntutan hukum (ontslag van rechts vervolging)

Putusan pengadilan berupa lepas dari segala tuntutan adalah putusan yang dikeluarkan berdasarkan pemeriksaan di persidangan pengadilan, majelis hakim berpendapat bahwa terdakwa terbukti secara syah dan meyakinkan bersalah telah melakukan perbuatan yang didakwakan kepadanya tetapi perbuatan tersebut bukan merupakan tindak pidana maka pengadilan menjatuhkan putusan lepas dari segala tuntutan pidana sebagaimana ditentukan dalam pasal 191 ayat (2) KUHAP atau terdakwa tidak dapat dipertanggungjawabkan karena adanya alasan pemaaf maupun alasan pembenar.

\subsection{Karakteristik putusan pengadilan}

Berikut karakteristik putusan pengadilan ${ }^{13}$ :

a. Putusan Pengadilan yang Telah Berkekuatan Hukum Tetap

Secara teori dan praktik suatu putusan pengadilan dapat dieksekusi apabila putusan telah berkekuatan hukum tetap. Pengertian putusan yang telah berkekuatan hukum tetap adalah apabila terdakwa maupun penuntut umum telah menerima putusan atau jika upaya hukum tidak digunakan oleh pihak yang berhak sehingga masa tenggang waktu untuk mengajukan upaya hukum terlewati atau upaya hukum telah diajukan

12 Tim Penyusun Modul Badan Diklat Kejaksaan RI, Modul Eksekusi, 12.

13 Ibid., 13-14. 
oleh pihak berhak tetapi kemudian upaya hukum yang telah diajukan kemudian dicabut atau putusan Mahkamah Agung dalam pemeriksaan untuk kasasi.

Sesuai ketentuan pasal 270 KUHAP panitera pengadilan mengirimkan salinan putusan pengadilan untuk dilaksanakan oleh Jaksa. KUHAP tidak mengatur dalam jangka waktu berapa lama panitera mengirimkan salinan putusan kepada Jaksa. Mahkamah Agung memberikan batas jangka waktu pengiriman, ialah dalam surat Edaran Mahkamah Agung Nomor 21 Tahun 1983 tanggal 8 Desember 1983, panitera diwajibkan mengirimkan salinan putusan kepada Jaksa paling lambat 1 minggu untuk perkara APB dan paling lambat 14 hari untuk perkara APS. Dalam hal putusan Mahkamah Agung karena telah mempunyai kekuatan hukum tetap, jaksa dapat mengeksekusi cukup dengan petikan putusan, tanpa menunggu salinan keputusan.

b. Putusan Pengadilan yang Belum Berkekuatan Hukum Tetap

Pada prinsipnya suatu putusan Pengadilan yang belum berkekuatan hukum tetap, karena terdakwa dan ataupun Jaksa Penuntut Umum tidak menerima putusan Eksekusi 14 Pengadilan dengan mengajukan upaya hukum, maka putusan Pengadilan tersebut belum dapat dilaksanakan (dieksekusi) oleh Jaksa (Pasal 270 KUHAP).

\subsection{Instrumen dan kebijakan putusan pengadilan hanya sah dan mempunyai kekuatan hukum}

Pasal 195 KUHAP, menyatakan bahwa semua putusan pengadilan hanya sah dan mempunyai kekuatan hukum apabila diucapkan di sidang terbuka untuk umum. Dari pasal tersebut, dapat diambil pengertian sebagai berikut ${ }^{14}$ :

a. Putusan pengadilan berlaku sah dan mempunyai kekuatan hukum apabila diucapkan di sidang pengadilan yang terbuka untuk umum;

b. Semua keputusan tanpa kecuali harus diucapkan dalam sidang yang terbuka untuk umum. Putusan yang diucapkan dalam sidang tertutup dengan sendirinya tidak sah dan tidak mempunyai kekuatan hukum yang mengikat, sekalipun dalam perkara kesusilaan dan perkara yang terdakwanya anak-anak.

Suatu putusan pengadilan dapat dieksekusi apabila putusan telah berkekuatan hukum tetap. Pengertian putusan yang telah berkekuatan hukum tetap yakni:
a. Apabila terdakwa maupun penuntut umum telah menerima putusan;
b. Jika upaya hukum tidak digunakan oleh pihak yang berhak, sehingga masa tenggang waktu untuk mengajukan upaya hukum terlewati;
c. Upaya hukum telah diajukan oleh pihak berhak, namun upaya hukum yang diajukan kemudian dicabut;
d. Putusan Mahkamah Agung dalam pemeriksaan untuk kasasi.

14 Gatot Supramono, Surat Dakwaan dan Putusan Hakim yang Batal Demi Hukum (Jakarta: Djambatan, 1998), 111. 
Putusan perkara pidana dalam peraturan perundang-undangan terdapat ketentuan yang mengatur mengenai putusan yang mempunyai kekuatan hukum tetap berkaitan perkara pidana, yakni dalam penjelasan pasal 2 ayat (1) Undang-Undang Nomor 22 Tahun 2002, yang menyatakan putusan pengadilan yang telah memperoleh kekuatan hukum tetap adalah:

a. Putusan pengadilan tingkat pertama yang tidak diajukan banding setelah waktu tujuh hari sesudah putusan dijatuhkan atau setelah putusan diberitahukan kepada terdakwa yang tidak hadir, sebagaimana diatur dalam Pasal 233 ayat (2) juncto Pasal 234 Ayat (1)UU No. 8 Tahun 1981 tentang Hukum Acara Pidana (KUHAP), kecuali untuk putusan bebas (vrijspraak), putusan lepas dari segala tuntutan hukum (onslag van rechts vervolging), dan putusan pemeriksaan acara cepat karena putusan-putusan tersebut tidak dapat diajukan banding (Pasal 67 KUHAP);

b. Putusan pengadilan tingkat banding yang tidak diajukan kasasi dalam waktu 14 (empat belas) hari sesudah putusan pengadilan yang dimintakan kasasi itu diberitahukan kepada terdakwa (Pasal 245 Ayat 1 Jo. Pasal 246 Ayat 1 KUHAP);

Putusan kasasi. Selama putusan belum mempunyai kekuatan hukum tetap, upaya peninjauan kembali tidak dapat dipergunakan. Terhadap putusan yang demikian hanya dapat ditempuh upaya hukum biasa berupa banding atau kasasi. Upaya hukum peninjauan kembali baru terbuka setelah upaya hukum biasa (berupa banding dan kasasi) telah tertutup. Upaya hukum peninjauan kembali tidak boleh melangkahi upaya hukum banding dan kasasi. Pengaturan secara umum upaya hukum peninjauan kembali diatur dalam Pasal 263 sampai Pasal 269 KUHAP. Putusan perkara pidana yang dapat diajukan peninjauan kembali adalah putusan pengadilan yang telah memperoleh kekuatan hukum tetap, kecuali putusan bebas atau lepas dari segala tuntutan hukum (Pasal 263 Ayat 1 KUHAP).

\section{Wewenang Jaksa sebagai Pelaksana Putusan Eksekutorial Putusan Pengadilan yang Telah Mempunyai Kekuatan Hukum Tetap}

\subsection{Eksekusi dalam putusan pidana dan sistem peradilan pidana}

Pelaksanaan putusan pengadilan yang telah mempunyai kekuatan hukum tetap dalam perkara pidana dilakukan oleh jaksa, dan oleh karena itu salinan putusan akan diberikan kepadanya oleh panitera15. Pelaksaan pidana penjara atau lembaga pemasyarakatan, sedangkan pidana mati dilakukan di muka umum. Eksekusi dalam pelaksanaan putusan pidana juga diawasi oleh hakim yang ditunjuk khusus guna membantu ketua dalam melakukan pengawasan dan pengamatan (Pasal 277 KUHAP). Penetapan sanksi dalam suatu perundang-undangan pidana bukanlah sekedar masalah teknis perundangundangan semata, melainkan bagian tidak terpisahkan dari substansi atau materi

15 Pasal 270 KUHP. Lihat di Fiona L. Pelafu, "Pelaksanaan Putusan Pengadilan dalam Perkara Pidana Berdasarkan Kitab Undang-Undang Hukum Acara Pidana,” Lex Crimen VI, no. 3 (2017): 89. 
perundang-undangan tersebut. Masalah penalisasi, depenalisasi, kriminalisasi, dan dekriminalisasi harus dipahami secara komprehensif dengan segala aspek persoalan substansi atau materi perundang-undangan pada tahap kebijakan legislasi ${ }^{16}$.

Eksekusi dalam sistem peradilan pidana di Indonesia masuk dalam tahap-tahap penegakan hukum pidana, semua tahap tersebut meliputi: tahap formulasi, tahap aplikasi, dan tahap eksekusi. Tahap eksekusi yaitu tahap penegakan atau pelaksanaan hukum pidana secara kongkret oleh aparat-aparat pelaksanaan pidana.

Berdasarkan undang-undang yang berlaku, Jaksa diberi tugas dan wewenang sebagai pelaksana putusan pengadilan. dalam melaksanakan putusan pengadilan dan penetapan hakim, kejaksaan harus memperhatikan nilai-nilai hukum yang hidup dalam masyarakat dan perikemanusiaan berdasarkan Pancasila tanpa mengesampingkan ketegasan dalam bersikap dan bertindak. Melaksanakan putusan pengadilan termasuk juga melaksanakan tugas dan wewenang mengendalikan pelaksanaan hukuman mati dan putusan pengadilan terhadap barang rampasan yang telah dan akan disita untuk selanjutnya dijual lelang.

\subsection{Tupoksi utama eksekusi dalam Kejaksaan Republik Indonesia}

Eksekusi merupakan salah satu tupoksi utama Kejaksaan Republik Indonesia yang diamanatkan dalam Undang-Undang Nomor 16 Tahun 2004 tentang Kejaksaan Republik Indonesia. Oleh karena itu, apabila mengabaikan pelaksanaan eksekusi terhadap perkara yang telah berkekuatan hukum tetap adalah suatu bentuk kelalaian yang serius dan terancam sanksi kode etik maupun peraturan disiplin pegawai negeri sipilit.

Kejaksaan adalah satu-satunya lembaga eksekutor sebagai pelaksana eksekusi putusan pengadilan. eksekutor merupakan suatu pihak yang mempunya kewenangan untuk merampas, menindak ataupun melaksanakan suatu putusan berdasarkan ketentuan atau undang-undang yang berlaku.

Eksekutor berasal dari kata eksekusi yang artinya pelaksanaan putusan pengadilan, yakni pelaksanaan putusan hakim atau pelaksanaan hukuman pengadilan (khususnya hukuman mati); penyitaan atau penjualan seseorang atau lainnya karena berutang. Adapun eksekutor dalam kamus besar bahasa Indonesia adalah orang yang melaksanakan eksekusi. Untuk kewenangan kejaksaan di bidang pidana yang menyangkut tentang eksekutor merupakan tindakan dari pihak kejaksaan sebagai eksekutor (pelaksana) yaitu melaksanakan penetapan hakim dan putusan pengadilan yang telah mempunyai kekuatan hukum tetap.

Pelaksanaan eksekusi putusan pengadilan yang memiliki kekuatan hukum tetap harus ditaati oleh semua pihak yang terlibat, baik aparatur penegak hukumnya yaitu jaksa maupun terpidana. Makna eksekusi yaitu pihak yang telah divonis mau tidak mau

16 Rika Maida Putri, "Analisis Eksekusi Terhadap Putusan Pengadilan Tanpa Mencantumkan Identitas Terdakwa (Studi Putusan Perkara PN.Ktb No.11/Pid.Sus.Anak/PN.Kbu)" (Universitas Bandar Lampung, 2016), 39.

17 Peraturan Pemerintah Republik Indonesia Nomor 53 Tahun 2010 tentang Disiplin Pegawai Negeri Sipil. 
menerima secara sukarela dan menaatinya, sehingga putusan tersebut dapat dipaksakan kepadanya dengan bantuan kekuatan umum ${ }^{18}$.

Pelaksanaan eksekusi dilakukan oleh jaksa sebagaimana telah diatur dalam Pasal 270 KUHAP. Sebelum pelaksanaan eksekusi, panitera harus mengirimkan salinan putusan kepada kejaksaan. Apabila salinan belum diterima oleh kejaksaan, maka terpidana belum bisa di eksekusi.

Terdapat perbedaan dalam pelaksanaan putusan pengadilan terhadap terpidana yang sebelumnya dilakukan penahanan dengan terpidana yang sebelumnya tidak dilakukan penahanan. Apabila terpidana sebelumnya dilakukan penahanan, maka pelaksanaan putusan pengadilan terhadap terpidana dilakukan dengan cara melakukan penahanan lanjutan sesuai dengan berapa tahun pidana penjara yang dijatuhkan dikurangi berapa lama terpidana tersebut sebelumnya dilakukan penahanan. Namun, pelaksaan putusan pengadilan akan berbeda dan mendapatkan perlakuan yang lebih spesifik apabila terpidana sebelumnya tidak dilakukan penahanan, pihak Kejaksaan akan memanggil terpidana untuk hadir ke Kejaksaan terlebih dahulu.

Saat terpidana sudah berada di tangan Kejaksaan jaksa akan membuat Berita Acara Pelaksanaan Putusan (BA8) dan selanjutnya terpidana dibawa ke Lembaga Permasyarakatan dengan dilampirkan surat-surat sebagai berikut:

a. Putusan pengadilan yang mempunyai kekuatan hukum tetap;

b. Surat perintah pelaksanaan putusan (P-48);

c. Berita acara pelaksanaan putusan (BA-8); serta

d. Surat perintah penahanan beserta berita acara penahanan, apabila terpidana dilakukan penahanan sebelumnya.

\subsection{Tidak semua putusan pengadilan mempunyai kekuatan eksekutorial}

Eksekusi putusan merupakan tindakan yang perlu dilakukan untuk memenuhi tuntutan jaksa penuntut umum kepada terdakwa. Tidak semua putusan pengadilan mempunyai kekuatan eksekutorial, artinya tidak semua putusan pengadilan dapat dieksekusi. Putusan yang belum dapat dieksekusi adalah putusan yang belum dapat dijalankan, pada prinsipnya hanya putusan yang telah mempunyai kekuatan hukum yang tetap yang dapat dijalankan pada asasnya putusan yang dapat dieksekusi adalah putusan yang memperoleh kekuatan hukum yang tetap, karena dalam putusan yang telah berkekuatan hukum yang tetap telah terkandung wujud hubungan hukum yang tetap dan pasti antara pihak yang berperkara ${ }^{19}$.

Hakim dalam menentukan putusan yang akan dijatuhkan kepada terdakwa wajib mengolah dan memproses data-data yang diperoleh selama proses persidangan, dalam hal ini bukti-bukti, keterangan saksi, pembelaan terdakwa, serta tuntutan jaksa maupun

18 Andi Hamzah, Hukum Acara Pidana Indonesia (Jakarta: Sinar Grafika, 2009), 14.

19 Suryono Sutarto, Hukum Acara Pidana Jilid II (Semarang: Badan Penerbit UNDIP, 2008), 128. 
muatan psikologis. Sehingga keputusan yang akan dijatuhkan kepada terdakwa dapat didasari oleh rasa tanggung jawab, keadilan, kebijaksanaan, profesionalisme dan bersifat obyektif.

\section{Kesimpulan}

Putusan pengadilan dapat dieksekusi apabila putusan telah berkekuatan hukum tetap. Secara hukum, pelaksanaan putusan tersebut dilakukan oleh penegak hukum, yakni jaksa yang berada di bawah naungan lembaga Kejaksaan Republik Indonesia. Adapun wewenang jaksa dalam melakukan pelaksanaan putusan pengadilan yang telah mempunyai kekuatan hukum sesuai dengan peraturan perundang-undangan yang berlaku. Dalam melakukan pelaksanaan putusan atau eksekusi jaksa harus memperhatikan nilai kemanusiaan dan keadilan. Selain itu bahwa wewenang Jaksa sebagai pelaksana putusan yang telah mempunyai kekuatan hukum tetap adalah kewenangan atribusi yaitu kewenangan yang berasal dari Undang-Undang, oleh sebab itu kedudukan dan wewenang jaksa dalam melaksanakan tugas dan fungsinya haruslah independen yaitu terlepas atau bebas dari campur tangan pihak mana pun, serta harus dipastikan agar tidak berpihak pada kepentingan pihak-pihak tertentu.

\section{Daftar Pustaka}

Cohen, Morris L., dan Kent C. Oslon. Legal Research. St. Paul, Minn: West Publishing Company, 1992.

Effendy, Marwan. Kejaksaan Republik Indonesia, Posisi dan Fungsinya dari Perspektif Hukum. Jakarta: Ghalia Indonesia, 2007.

Hamzah, Andi. Hukum Acara Pidana Indonesia. Jakarta: Sinar Grafika, 2009.

Indra, R. "Pelaksanaan Putusan (Eksekusi) Perkara Pidana yang Berkekuatan Hukum Tetap." Doktor Hukum. Last modified 2019. Diakses Mei 2, 2020. https://www.doktorhukum.com/pelaksanaan-putusan-eksekusi-perkara-pidanayang-berkekuatan-hukum-tetap/.

Marzuki, Peter Mahmud. Penelitian Hukum. 12 ed. Jakarta: Kencana, 2016.

Pelafu, Fiona L. "Pelaksanaan Putusan Pengadilan dalam Perkara Pidana Berdasarkan Kitab Undang-Undang Hukum Acara Pidana.” Lex Crimen VI, no. 3 (2017): 86-93.

Pramudya, Kelik, dan Ananto Widiatmoko. Pedoman Etika Profesi Aparat Hukum. Jakarta: Pustaka Yustisia, 2010.

Putri, Rika Maida. “Analisis Eksekusi Terhadap Putusan Pengadilan Tanpa Mencantumkan Identitas Terdakwa (Studi Putusan Perkara PN.Ktb No.11/Pid.Sus.Anak/PN.Kbu)." Universitas Bandar Lampung, 2016.

Samosir, Samuel Saut Martua. "Penerapan Penggunaan Irah-Irah 'Demi Keadilan Berdasarkan Ketuhanan Yang Maha Esa' dalam Konteks Pencapaian Keadilan." Jurnal $\begin{array}{llllll}\text { Supremasi } & 9 & & & & \text { (2019): }\end{array}$ https://ejournal.unisbablitar.ac.id/index.php/supremasi/article/view/790. 
Sinaga, Dahlan. Kemandirian dan Kebebasan Hakim Memutus Perkara Pidana dalam Negara Hukum Pancasila, Suatu Perspektif Teori Keadilan Bermartabat. Bandung. Nusa Media, 2015.

Supramono, Gatot. Surat Dakwaan dan Putusan Hakim yang Batal Demi Hukum. Jakarta: Djambatan, 1998.

Sutarto, Suryono. Hukum Acara Pidana Jilid II. Semarang: Badan Penerbit UNDIP, 2008.

Syahrani, Riduan Bakti. Materi Dasar Hukum Acara Perdata. Bandung: Citra Aditya Bakti, 2000.

Tim Penyusun Modul Badan Diklat Kejaksaan RI. Modul Eksekusi. Jakarta: Badan Pendidikan dan Pelatihan Kejaksaan Republik Indonesia, 2019. 